Abstracta Iranica

Revue bibliographique pour le domaine irano-aryen

Volume 42-43 | 2021

Comptes rendus des publications de 2019-2020

\title{
Francesca Fiaschetti (ed.). Diplomacy in the Age of Mongol Globalization
}

\section{Simon Berger}

\section{(2) OpenEdition}

1 Journals

\section{Édition électronique}

URL : https://journals.openedition.org/abstractairanica/53731

DOI : 10.4000/abstractairanica.53731

ISSN : 1961-960X

Éditeur :

CNRS (UMR 7528 Mondes iraniens et indiens), Éditions de l'IFRI

Référence électronique

Simon Berger, «Francesca Fiaschetti (ed.). Diplomacy in the Age of Mongol Globalization », Abstracta Iranica [En ligne], Volume 42-43 | 2021, document 22, mis en ligne le 30 décembre 2021, consulté le 14 décembre 2022. URL : http://journals.openedition.org/abstractairanica/53731; DOI : https://doi.org/ 10.4000/abstractairanica.53731

Ce document a été généré automatiquement le 14 décembre 2022.

Tous droits réservés 


\title{
Francesca Fiaschetti (ed.). Diplomacy in the Age of Mongol Globalization
}

\author{
Simon Berger
}

\section{RÉFÉRENCE}

Francesca Fiaschetti (ed.). Diplomacy in the Age of Mongol Globalization. Eurasian Studies, vol. 17/2, Special Issue, April 2020, Leyde: Brill.

1 Le dossier rassemblé dans ce volume de la revue Eurasian Studies est en grande partie issu de l'atelier éponyme organisée par Michal Biran, Francesca Fiaschetti et Marie Favereau, qui s'est tenu à Jérusalem les 30 et 31 mai 2016. Si certaines communications données alors n'ont pas été reprises, certains auteurs présents ont modifié leur sujet et d'autres ont été invités à participer. Le résultat est un ensemble de huit articles, en plus d'une introduction par l'éditrice, portant sur les échanges diplomatiques entre les Mongols de l'Empire gengiskhanide et le monde extérieur, ou bien à l'intérieur même de l'empire :

2 - M. Vér, «Chancellery and Diplomatic Practices in Central Asia during the Mongol Period as Shown in Old Uyghur and Middle Mongolian Documents »;

3 - Y. Qiu, « Gift-Exchange in Diplomatic Practices during the Early Mongol Period»; (cf. le compte rendu dans ce même numéro d'AbstIr)

4 - J. Valtrová, «Christian Material Culture and the Mongols: the Case of William of Rubruck »;

5 - M. Ciocchetti, «Contacts between the mongols and the Latin West from the Point of View of the Italian Chronicles in the Second Half of the Thirteenth Century »;

6 - F. Fiaschetti, «Voices from Afar: Yuan Diplomacy between Ritual and Practice» ;

7 - N. O. Arom, "In-Ger" and "Outer" Diplomacy - Ilkhanids Contacts with the Mongols and the Outside World, 1260-1282»; (cf. le compte rendu dans ce même numéro d'AbstIr) 
8 - D. Bayarsaikhan, « Mongol Diplomacy of the Alamut Period »; (cf. le compte rendu dans ce même numéro d'AbstIr)

9 - K. Golev, «Intra-Mongol Diplomacy and Witch-Hunt during the Dissolution of the Empire: the Witchcraft Trial at the Court of Hülegü». (cf. le compte rendu dans ce même numéro d'AbstIr)

10 Quatre de ces contributions, ayant plus particulièrement trait aux champs concernant Abstracta Iranica, sont recensées plus en détails dans ce volume. Le dossier dans son entier fait l'objet d'un compte rendu complet dans le numéro $36 \mathrm{du}$ Bulletin critique des Annales islamologiques.

\section{AUTEURS}

\section{SIMON BERGER}

Doctorant EHESS, CETOBAC, Paris 